Maria Łuszczyńska, Ph.D.

The Maria Grzegorzewska

Academy of Special Education in Warsaw

\title{
TRADITION, PERSPECTIVES AND RECOMMENDATIONS CONCERNING EDUCATION FOR OLD AGE
}

\author{
We now know a lot about what enables us to \\ put off decrepitude. It is, above all, activity that is \\ appreciated and useful and then also a vivid pro- \\ pensity to have one's interests satisfied.
}

Aleksander Kamiński

\section{Introduction}

In a fit of good mood, a professor of logic explained to his students once that from the perspective of logic a statement "All people are mortal" was not true. In order to prove this statement right a person who could be able to verify it would be needed, but the mere fact of such person's existence would disapprove the truthfulness of its content. Thus logic comes to the rescue of hope for immortality, this eternal desire that probably all people envious of the angels as well as keen readers of vampire stories or old legends about people who did not die, cherish. Old people have always regretted their lost youth, while young ones have successfully avoided the thought of sharing the fate of the elderly they observed. Old age is regarded as a curse or unavoidable evil, time of sadness, last period of life leading to death.

It is not the aim of this paper to explore or analyse different known definitions of senility. I would like to emphasis here that my argument focuses on the psychosociological aspect of the phenomenon, and therefore the following definition of senility by American gerontologist A. Lansing is used as reference for my argumentation: "[aging is] an advancing process of unfavourable changes, usually connected with the passage of time, revealing itself after reaching maturity and leading to death." (Lansing, 1952). The expression "unfavourable changes" 
designates disturbance of an equilibrium or homeostasis that every organism seeks to maintain. This disturbance further causes instability of elderly people's social position.

A duality of human life is manifested in analyses of senility. On the one hand, elderly persons constitute an indispensable element of the society; meanwhile, on the other hand, they are marginalized. Moreover, it is remarkable that while writing, talking or reading about the elderly, people tend to - perhaps subconsciously - never use "we, the elderly" clause, that is, first-person narratives (either in singular, in accordance with individualistic concepts or in plural, as representing social concepts). Narratives of the elderly always take form of third-person, either singular or plural. When we connect this to how unavoidable each narrator's mortality is as well as to the fact that senility has been to a large extent repressed in our consciousness and imaginary representations of our own life $^{1}$ far reaching consequences may be drawn from given situation, with advanced carelessness about the elderly as a numerous group of marginalized and helpless individuals, to start with.

The main point of the argument relies in a conviction that becoming aware of one's position in the passage of time is the key element of education for the elderly. It is only when the process of building time-consciousness, which is explored in the last part of the paper, is completed that will successful engagement in problems and interests of the elderly be possible for institutions and social movements. This conviction derives from an assumption that the people standing behind these institutions can be involved in activities for the sake of seniors only after they comprehend their own interest and their own needs there. Otherwise, it is asserted, a mental and real marginalisation is going to be an advancing process and no external influence - either through a rule, obligation, law or reference to morality and humanitarianism - will be capable of a successful defence of the rights of the elderly.

\section{Brief Review of Perspectives on Education for the Elderly}

Securing possibly longest lasting self sufficiency has been the prime purpose of education for the elderly in the gerontologic tradition. There are three basic premises serving for assessment of prosperity in old age, according to the

\footnotetext{
${ }^{1}$ Let me illustrate it with a situation that frequently reoccurs during workshops with various age groups, devoted to social work with the elderly in their place of living. I always dedicate the first session to activities aimed at inspiring students to reflect on senility. In a short exercise consisting in associating "senility" with reference to oneself, usually the reply: "I will not become old" is the most common, and only some 2-3 persons out of ca 25 in the group will allow their imagination to assume that they will also grow old, which does not mean that their emotions connected to this image are pleasant.
} 
successful ageing theory presented by J.W. Rowe and R.L. Kahn. These are: low level of disability, high level of self-sufficient physical performance, and active involvement as well as interest in life (Rowe, Kahn, 1997). It is interesting that according to these criteria also the psychosocial position of the youngest generations could apparently be assessed negatively, which in turn should cause not really the development of education for the elderly but its inclusion into a wider scope of management of life cycles.

It is necessary to distinguish two aspects of education devoted to the elderly - education for old age and education in old age. A. Kamiński, pioneer of the Polish pedagogical research with respect to the elderly, introduced this distinction. His main focus was upbringing till old age, however in view of his concept of long-life-learning as well as the whole of his pedagogical thought it is permissible, for the sake of this paper, to consider upbringing as a derivative of education. Upbringing for old age is, according to Kamiński, an introduction into a certain knowledge, carried out from youth till middle adulthood. This knowledge includes the needs, forms of activity, limitations and abilities of seniors, and types of support offered to them, beside their rights and obligations or moral and ethical duties. This knowledge is by default directed at "future seniors" and its aim is to teach younger generations how they should support elderly people who are presently members of the society.

Upbringing in old age means enriching the knowledge, abilities and habits in all subsequent stages of late adulthood. Senior groups are the direct target of these educational activities. The curriculum of upbringing in old age includes knowlegde about ways of maintaining possibly longest lasting self-sufficiency, responsibility for social position including knowledge of techniques of preventing negative social image of the elderly, development of cognitive activity and motivation for setting one's life on the right course and giving it the right meaning, enhancement of creative abilities for the sake of time management and expansion of one's interests as well as participation in continuous education (Kamiński, 1978).

The concept of education for old age in Poland reaches back to the 16th and 17th century. It was promulgated by S. Maricjusz in his book of 1551 entitled O szkołach, czyli akademiach ksiag dwoje [Two Volumes on Schools i.e. Academies] (Maricjusz, 1975) and J.A. Komeński in his work Pampaedia of 1656 (Komeński, 1973). Komeński proposed to establish eight educational institutions operating in accordance with phases of life, including a "school for senility" (Schola Senii) and a "school for death" (Schola Mortis). Thanatotherapeutical institutions may be considered as a contemporary counterpart to "schools" whose purpose was to explore the transient aspect of human life. There are a number of "schools of dying" in Poland, and these established around the world - including a psychological training consisting in burial alive - enjoy great popularity ${ }^{2}$. Schools of this

${ }^{2}$ Compare: $<$ http://www.focus.pl/cywilizacja/zobacz/publikacje/pogrzebani-zywcem/>[10.10.2011]. 
sort, established in Japan for instance, serve the purpose of spreading awareness about human mortality and encourage to looking for sense in life.

Gerontologists have been for years discussing and presenting various perspectives on the issue of preparation for old age, however not many of them opened up to participate in the debate on managing different phases of life. Thus only problems of people who are already old have been taken into account. The people who are still professionally active are neglected and marginalised in the gerontologist studies, as if these people were not going to become old within 10-30 years. Meanwhile, neglect of their education for old age may serve only for maintaining the status quo. I will hereby sketch selected gerontologic standpoints and hence expose the premises for my own argument on education for old age.

"Learning throughout lifetime" - is a slogan that according to O. Czerniawska is going to become a motto for the 21 st century. Czerniawska's study seems to be a part of a larger current whose aim is to "study in order to live" and whose background was created by such authors as Protagoras, Plato, H. Spencer, L. Krzywicki, E. Fromm, B. Suchodolski (Stopińska-Pająk, 2009). Several educational principles are connected to this slogan and they are carefully applied into the education for old age. Here are the principles: to study in order to act; to study in order to cohabit; to study in order to know; to be in order to study. The purpose of implementing these principles is not just to participate in typical educational formation, but also to build a certain awareness thus becoming conscious of the fact that life itself creates educational situations. Studying, both in the traditional sense but also as innovative approach to learning, teaches opening up towards oneself, others and the world. Thus, studying is to become a manner of living, a lifestyle.

According to H.R. Moody, an American gerontologist, an elderly person is particularly obliged to develop, in order to comprehend not just oneself but also others, and above all to grasp the sense of permanent changes taking place in the surrounding world. Thanks to personal development an elderly person can set models of life for future generations, actively participate in the functioning of the social, cultural and even political environment (Orzechowska, 2003).

An American psychologist involved with projects connected with experimental learning - J. Mezirow - proposes a concept of studying comprehended as choice-making. He claims that choices conditioning learning always refer to three spheres: present, past and future (Mezirow, 1990). It is through critical reflection that people realise their own psychological and cultural premises that have had impact on reviewing of their own lives within the dimension of time and chronological structure.

All above mentioned elements are reflected in my concept of education for old age, understood as awareness of one's own position in the passage of time. 


\section{Premises of Education for Old Age}

Taking into account the demographic aspect of changes in the structure of the world human population is the most important reason for search of positive solutions in the area of senility sensu lato. The results following from the process of ageing of the societies and social problems connected to it, which present the situation of the elderly, have become the focus of interest of gerontologists, geriatrists, psychologists, sociologists and social politicians, and are being thoroughly analysed in literature on the subject (Szarota, 2004). The percentage of people living up to very advanced old age steadily grows, globally. Demographic ageing of societies has become a symbol of the 20th century. There is a debate over E. Gee's notion of apocalyptic demography whose effects for societies amount to:

- homogenisation of groups of seniors,

- blaming elderly persons,

- perception of the process of ageing as a social problem,

- instilling inter-generational conflicts based on the discussion about intergenerational (in)justice or (in)equality,

- unconditional and constant connecting the process of ageing with social politics (Szukalski, 2009).

P. Szukalski completes the consequences following from apocalyptic demography with an additional assumption: that is, inevitable deterioration of the state of health, cognitive abilities, and social and professional competence. This conviction leads to pressure exerted on seniors for "adjusting" to the changing situation and for abandoning their current social roles. This means that the state must compensate the deficits resulting from changing previous roles, and it is being done at the expense of younger generations (Szukalski, 2009, 26-27). This attitude makes frustrations and social conflicts grow even stronger and can lead to an increase in the phenomenon called "ageism". The latter consists in creating stereotypes and unequal treatment of individuals based on their belonging to different age groups (Szukalski, 2004, 11-15; Szukalski \& Kowaleski, 2008, 153-184).

Apart from demographic tendencies and ageistic attitudes and difficult social situation or need to seek positive solutions for the role of senility in the life of the human, there are several other problems: lack of awareness of one's own process of ageing or its consequences, growth of the elderly people's population, and negative social attitude. The latter is characterised by a specific dualism of a positive image of seniors-family members against simultaneous negative or hostile attitude towards seniors from the neighbourhood or strangers who we share public spaces with.

Withdrawal from social roles of elderly people whose state of health, physical and intellectual capacities as well as social potential enables them to participate, is another reason why education for old age should be explored. These persons 
exclude themselves on their own in reaction to social pressure resulting from above mentioned factors. ${ }^{3}$ In connection to this it is necessary to significantly redefine efforts to be made for the sake of education for old age. Perhaps more attention should be paid to its internal and personal aspects than to institutional solutions that take form of external activities or social action. The latter should certainly not be altogether abandoned, but focus of attention should be shifted.

\section{Project of Education for Old Age}

It is easy to observe from everyday experience, that changes in life start with a decision taken on the intellectual level. Certainly, such decision can be supported by our physical or emotional state, however it is the decision about taking a certain attitude which determines the extent of change to be implemented. This phenomenon concerns foremost, for instance, persons suffering from cancer, as a transformation of the way of thinking - achieved through conscious decision making - is crucial for the sake of their recovery. Ever more sociological and psychological studies demonstrate that the quality of life depends on attitude. Authors of the article entitled Happy people live longer present a detailed review of literature in support of this thesis (Diener, Chan, 2011).

Biological ageing depends to an extent on psychic attitude to this process as well as on observing a number of principles linked to management of everyday life. Researchers have identified factors common for the population of people known for longevity. A life full of social interactions and professional activity are first and most important factors strengthening longevity, followed by happy married life, close friendly relationships and physical activity. Adequate motivation for decision making, based on the rule of free will, as opposed to pressure in decision making, is another advantage. If we build social interactions it is because we draw genuine joy and pleasure from them, if we undertake physical activity, it is also for the enjoyment of it and not due to an obligation, if we work, it is in

${ }^{3}$ My own working calculations based on data from 2006 indicate that ca $\mathbf{5}$ million people at the age of $60+(!)$ are socially inactive in Poland. They probably limit their activity to their own living place and public space needed for the sake of everyday life matters. The following criteria were taken into account: physical state that excludes from continuous care, provided either by relatives and friends or institutional, completed 60 years of age, and neglecting the number of people participating in institutional forms of activisation such as "Third Age University" or "Seniors' Clubs". Also, about 1 million people who receive a permanent nursing subsidy from the Social Insurance Office (Zaktad Ubezpieczeń Spolecznych) were excluded. This means that every eighth Pole may find him/herself in the situation of "social concealment" and the only activity filling up his/her life is "waiting for death". This perspective is horrifying not only from the point of view of those who are pensioners today, but also with respect to the future of younger generations who are not prepared for this model of ageing. 
an area that brings us satisfaction and not under pressure, in stress or by orders (Friedman, Martin, 2011) ${ }^{4}$.

If follows that good ageing starts with thought processes and with attitudes that people take as well as emotions that they experience. Therefore, the process of education for old age should be starting from efforts towards development of consciousness of one's position in the passage of time. Education for old age should be understood as becoming aware of the fact that as a human being I am placed in life within a framework of time and not independently of it while the passage of time concerns everybody else but myself. The latter conviction may be conceived as a result of a foremost timeless character of our mind that is a mysterious and immaterial faculty, sometimes referred to as "a divine gift". Nonetheless, regardless of the "spiritual" factor that displaces us beyond the framework of time, building of awareness of our position in time is a necessary first step towards an efficient and successful education for old age. A state of mind that provides tranquillity, acceptance of oneself as well as of one's past, present and future, including the perspective of death would - through internalisation of all stages of time - enable personal growth and prepare the elderly for unknown perspectives of the encroachment of time. In other words, the purpose of education for old age, conceived as prevention of unfavourable effects of living through senility relies in creating a situation when the human comprehends and accepts all transformations that are her or his share.

Building of the consciousness of being rooted in time serves as a premise for subsequent stages of education for old age. What are the methods of creating awareness of one's transitive position in time? The experience of the present is a crucial although remarkably difficult experience that establishes a perspective on time that enables progress. Excess of stress usually causes people, regardless of their age, to root their consciousness primarily in the past and in their own history or its events, which often results in holding oneself captive in the past life. Expectations, desires, dreams or plans that detach one from his or her here and now into an unknown and incomprehensibly distant future are another result of stress. Both of these attitudes sever the person from genuine presence in current situation. Such "un-timing" impacts one's contact with the present and causes one's separation from the reality of time. It often happens that medical examination of the state of internal organs reveals that the biological age of the organism differs from that expected of the actual age of the person (organs are too young

\footnotetext{
${ }^{4}$ This research was a follow up to an earlier one commenced in 1921 by a Stanford professor L. Terman who had surveyed a group of 1500 ten year olds in terms of their intelligence and other psychological characteristics. The investigation was carried out by researchers from the University of California who analysed further life stories of the participants of Terman's research, both living and dead. Based on these analyses psychologists have drawn a model personality and lifestyle of a long-living person.
} 
or too old, the latter more frequently). Symultaneously, psychological examination that establishes psychic age in reference to actual age of the person, often reveals that emotional or psychic maturity is irrelevant to actual age determined by the date of birth. This sort of time disproportion may be a cause of accumulation of stress, excessive biological exhaustion, psychic and somatic illnesses that inhibit growth and prevent the individual from experience of peacefulness or repose.

Rooting oneself in the present is necessary for the sake of re-establishing one's relation with the reality of time, attaining composure, experiencing joy or conscious managing one's own vital energy. This concerns both physical energy as well as that of psychic or emotional nature. Settlement in time leads also to development of one's spiritual potential that, regardless of age, is essential for finding meaning in every sphere of life (Fromm 1994). The ability to establish oneself in the present could become a method for solving developmental conflicts connected with the eight stages of human life mentioned above after E. Erikson. The last, eighth stage encompassing the period of life over 60, is characterised by a crisis concerning integration of the ego vs. despair. The period includes a positive review of one's life which requires wisdom and leads to the state of integration. Achievement of integration induces discovery of meaning in life and reaching an assurance about the value of one's choices in life, in spite of the fact that they could have been different. Lack of fear of death is a positive manifestation of integration. The experience of the present could certainly be helpful in solving conflicts concerning earlier stages of one's growth as well. On the other hand, exercising settlement in the present moment after 60 years of age could help achieving integration after previous unresolved crises. Adults whose ego is integrated are capable of reviewing their own past and regarding themselves as valuable persons. A failure to solve this crisis leads to despair, feeling of incompetence and regarding one's life as unfulfilled (Dembo, 1997, 371-376).

People who are currently seeking ways to experience the present utilise various methods of work with the body and through the body. It turns out that it is the state of the body and its experiences that play a key role for the emotions and the intellect in building up consciousness of its own transitive character. Known research leads to various kinds of activities with regard to the body, starting with care for health, preventive examination, learning to understand the body's signals, pain management, through care for a diet proper for each organism, systematic physical involvement, participation in various sports activities as well as movement trainings (for instant: yoga, tai-chi, qui-gong, dance activities), and finishing with meditation and building spiritual relations based on the work on the body. Various schools of spirituality have been going through a period of renaissance lately. They refer to the axioms of different religions. Schools of silence, prayer and meditation that teach building close relationships with the Absolute through 
the body can be found within Christianity, Judaism, and Hinduism. Interest in popular-scientific literature tackling the themes of spiritual growth concerned with experience of the present has increased lately (Kabat-Zinn, 1995, 2009; Tolle, 2003; Mindell, 2007).

A constructive relationship with the present inspires to experience primary solitude in its most existential dimension. This sort of solitude was analysed by philosophers like J.P. Sartre, T.W. Adorno, F. Nietzsche, Jose Ortega y Gasset, S. Kierkegaard to mention but a few recent thinkers (Tyburski, Domeradzki, 2006). Mystical thought is to a great extent based on the experience of solitude as well, as is manifest in the writings of St. John of the Cross or St. Bonaventura and even John Paul II. The experience of solitude becomes the main factor of spiritual growth and an offset of the way towards the Absolute, regardless of religion that provides notions and axioms (Carmody, Carmody, 2011).

This primary existential experience of solitude is a condition sine qua non for building all other relations secondary to it - with oneself, with other people, including the closest (immediate family) or more distant (relatives, friends, acquaintances, neighbours, cohabitants of the same region). I purposefully do not mention the relation with the Absolute as a condition for proper relations as such conviction makes a part of a religious paradigm while I am convinced that relations with oneself or other people are possible without a conscious, clearly defined and experienced relation with the Absolute. One can, on the other hand, debate the quality or depth of relationships when with or without the relation with the Absolute. I should leave the latter to individual decisions and insight. It is solitude that becomes a universal milestone in the education for old age, for everybody.

Solitude defines us in our relationship with ourselves and taming of solitude as well as ability to spend time with oneself is a derivative of it. This leads to development of a culture of hobbies, and the fact of entertaining interests beside professional activities is a favourable factor for undertaking actions enhancing activity of the elderly, which many surveys confirm (Czerniawska, 1998; Dzikomska, 2008). Besides, World Health Organisation has introduced the concept of successful ageing, which is ever more often identified with active ageing. The latter relies in modelling politics in such a way as to provide the elderly access to three spheres conditioning an optimum quality of life. These spheres are health, self-sufficiency and productivity. A conviction that happy ageing is a sum of (social and professional) activity that takes state of health as its goal is constitutive for active ageing. Activity is to be of both individual and group character therefore institutional and legal solutions ought to reinforce these forms of activity. They lead to an enhancement of self-sufficiency and thus to relieving the society of material and personal costs of care for the elderly as well as to raising of the sense of solidarity between generations, necessary for the sake of social unity (Walker, 2006). 
Once a person builds up a constructive relationship with himself or herself, the person is capable of building a relationship with the Other (Levinas, 1998). These others - parents, partners, children - can be offered unconditional love that protects them from destructive references to the past or present of the person who enters into these relations. Such person will set his or her closest aside from the sphere of pretence or expectations. This positive experience enables creation of new models of care and a core for intergenerational relations. An intergenerational exchange of beliefs, traditions, history and archetypes of relations whose fruit will be an ability of managing social relations takes place in the family in the context of the passage of time. It is there that one is able to find and define oneself in the context of intergenerational relations, to build an attitude of respect, exchange and tolerance for differences, both concerning age as well as social roles. It is compulsory for the sake of functioning in the society within the range of individual and social contexts and for fulfilling one's obligations and realising professional, consumer, personal and finally community oriented activities. A constructive and undisturbed attitude towards oneself based on the consciousness of one's transitory nature eventually leads to attitudes desired by the education for old age, that is elimination of social stereotypes, acceptance of implementation of activities aimed at anti-marginalising of the elderly, financing geragogic coaching and socialisation of the elderly, therapies and rehabilitation of the elderly, meeting of various needs of the elderly, which involves making seniors heard in the public debate. I have no illusions that tolerance for the elderly must be based in an individual personal experience and not in external activities.

A question remains unanswered though: who is supposed to "teach" education for old age and inspire to enter into primary experience? The very nature of the experience requires that its object and subject should be an individual, however relations with other people should serve as stimulants for gradual experience of mortality, solitude, transition and - eventually - integrity.

Education for old age should therefore begin in childhood, in the period before the child is introduced to social life by public educational institutions. Parents and guardians are the child's first partners in taming the transitory character of life. Referring to their own experience of change, finality or suffering they are capable of gradual familiarising of the child with the transitive nature of time and teach him/her to live in the present. A positive attitude of the parents themselves is the only condition for the success of this sort of education.

Educational, cultural and social institutions can take on the tasks connected to preparation for old age, later. Their duty would be to organise real situations referring to experiences of young, adult and elderly people. Exchange and coparticipation in given situations might facilitate a transformation of the psychic processes of all interacting participants, which would encourage mutual psychosocial enrichment. 


\section{Summary}

The process of changes founding the project of education for old age starts with the individual. The order of education for old age comprehended as building awareness of one's position in time begins from establishing one's relation to past and future. It can be done through activities of therapeutical character, through vivisection or through a process of building self-awareness according to the principle that everything that we experience (especially that which is painful) has a meaning and befalls us for a reason. A discovery of this meaning enables the individual to take a distanced perspective towards past events or future expectations. This in turn leads to searching for methods of work with one's body appropriate for the individual and aimed at rooting oneself in the present. A success in rooting oneself in the present causes a deep experience of solitude and primary existential fear. This experience serves as a foundation for the individual's relation towards oneself and leads to acceptance of one's existence. The latter is a necessary premise for successful relations with the closest environment, usually family, and further it creates positive, dynamic and constructive relation with other "social classes" - that is other generations and members of the individual's community. It seems that this strictly psychological journey is the only condition for a successful education for old age, as it is only the influence of such strong existential and universally valid experiences that can lead towards recognition of the importance of the process of ageing and to building solutions within social consciousness as well as institutional or legal solutions that follow from it. However, no external solutions of the problem of ageing of the society will have an appropriate impact without the individual's deep experience of time. Building of an awareness of one's position in time will cause a transformation of one's health, and social, professional, educational and personal attitudes. Only this process leads to a social change, not the other way round. It is also capable of meeting the tasks connected with traditional education for old age, such as:

- acquisition and development of abilities for planning one's own life in view of the perspective of ageing that can in its optimum form be a neutral state that will not inspire negative emotions,

- overcoming of individual and common stereotypes about ageing,

- developing different concepts on age-management with regard to the consciousness of roles and tasks for each stage in human life, without preference given to any of these stages,

- acquisition of readiness to making any changes necessary in life which is a direct result of creating a positive relation with one's past and future and of being truly aware of the present.

Introducing the individualistic model of education for old age will enable promotion of a positive, active image of the elderly in the public sphere. A society 
that favours active lifestyles for the elderly can take better advantage of the richness of experience and knowledge that its elder members possess. Such society has an image of ageing relevant to existential situation of the human and it is able to draw energy from the phenomenon of old age instead of perceiving it as a threat for its functioning.

\section{References}

Carmody D.L. Carmody J.T. (2011). Mistycyzm w wielkich religiach, Kraków: WAM.

Czerniawska O. (1998). Style życia w starości, Łódź: Wyd. WSHE.

Dembo M. H. (1997). Stosowana psychologia wychowawcza, Warszawa: WSiP.

Diener E., Chan M.Y. (2011). Happy People Live Longer. Subjective Well-Being Contributes to Health and longevity. Applied Psychology. Health and Well-Being, 3(1), p. 1-4.

Dzikomska A. (2008). Indywidualna aktywność życiowa jako czynnik przeciwdziałajacy negatywnym aspektom starzenia się. [In:] M. Kuchcińska [Ed.] Edukacja do i w starości. Bydgoszcz: Wyd. Kujawsko-Pomorskiej Szkoły Wyższej.

Friedman H.S., Martin L.R. (2011). The Longevity Project. Surprising Discoveries for Health and Long Life from the Landmark Eight-Decade Study. New Yor: Hudson Street Press.

Fromm E. (1994). Niech się stanie człowiek. Z psychologii etyki. Warszawa-Wrocław: Wyd. Naukowe PWN.

Kabat-Zinn J. (1995). Właśnie jesteś. Przewodnik uważnego życia. Warszawa: Wyd. Jacek Santorski.

Kabat-Zinn J. (2009). Życie piękna katastrofa. Mądrościa ciała i umystu możesz pokonać stres, choroby i ból. Warszawa: Czarna owca.

Kamiński A. (1978). Studia i szkice pedagogiczne. Warszawa: PWN.

Komensky J.A. (1973). Pampaedia. Wrocław: Ossolineum.

Kowaleski J.T., Szukalski P. (2008). (Ed.). Starzenie się ludności Polski-między demografia a gerontologia społeczna. Łódź: Wyd. UŁ.

Kuchcińska M. (Ed.), (2008). Edukacja do i w starości. Bydgoszcz: Wyd. Kujawsko-Pomorskiej Szkoły Wyższej.

Kuchcińska M. (Ed.), (2004). Zdrowie człowieka i jego edukacja gerontologiczna, Bydgoszcz: Wyd. Akademii Bydgoskiej im. Kazimierza Wielkiego.

Lansing A. What is ageing? Journal of Gerontology, 1952, 7.

Leszczyńska-Rejcher A. (2006). Człowiek starszy i jego wspomaganie - w stronę pedagogiki starości, Olsztyn: Wyd. Uniwersytetu Warmińsko-Mazurskiego.

Levinas E., (1998). Całość i nieskończoność. Esej o zewnętrzności. Warszawa: Wyd. Naukowe PWN.

Maricjusz S. (1955). O szkołach, czyli Akademiach ksiag dwoje. Wrocław: Ossolineum.

Mezirow J. (1990). Fostering Critical Reflection in Adulthood. A Guide to Transformative and Emancipator Learning. Oxford: Jossey-Bass Publishers.

Mindell A. (2007). Siła ciszy. Metody całodobowego świadomego śnienia. Katowice: Wyd. KOS.

Orzechowska G. Przygotowanie do starości. Edukacja Dorostych. 2003, 3, p. 16-23.

Pogrzebani żywcem, <http://www.focus.pl/cywilizacja/zobacz/publikacje/pogrzebani-zywcem/> [10.10.2011].

Rowe J.W., Kahn R.L. (1997). Successful ageing. The Gerontologist, 4, pp. 433-440.

Stopińska-Pająk A. (2009). Szkoła starości - być, aby się uczyć. [In:] A. Stopińska-Pająk [Ed.]. Edukacja wobec starości - tradycja i wspótczesność. Chowanna, Katowice: Wydawnictwo UŚ, pp. 11-25. 
Szarota Z. (2004). Gerontologia spoleczna i oświatowa. Zarys problematyki. Kraków: Wyd. AP.

Szukalski P. (2008). Ageizm - dyskryminacja ze względu na wiek, [In:] J.T. Kowaleski, P. Szukalski

(Ed.). Starzenie się ludności Polski - między demografia a gerontologia spoleczną. Łódź: Wyd. Ut.

Szukalski P. (2004). Dyskryminacja ze względu na wiek (ageizm) - przyczyny, przejawy, konsekwencje. Polityka społeczna, 2, pp. 11-15.

Szukalski P. (2009). Starzenie się ludności - wyzwanie XXI wieku, w: P. Szukalski (Ed.) Przygotowanie do starości. Polacy wobec starzenia się. Warszawa: IPS.

Tolle E. (2003). Potęga teraźniejszości. Kraków: Wyd. A.

Tyburski W., Domeradzki W. (Eds.), (2006). Zrozumieć samotność. Studium interdyscyplinarne. Toruń: Wyd. UMK.

Walker A. (2006). Active ageing. Maintaining health and autonomy across the life course. [In:] Geriatrics. Proceedings of the International Congress of Elderly Health, Istanbul, Turkey. pp. 107-113. 